УДК 1(091)

DOI https://doi.org/10.32837/apfs.v0i27.919

\author{
Л.Г. Павлишин \\ ORCID ID: https://orcid.org/0000-0001-5040-4538 \\ доктор філософських наук, професор, \\ професор кафедри філософії та суспільних наук \\ Тернопільського національного педагогічного університету імені Володимира Гнатюка
}

\title{
ОСНОВНІ ІДЕЇ Ф. НІЦШЕ У ПРАЦЯХ ДОСЛІДНИКІВ ЙОГО ТВОРЧОСТІ
}

Творчість Ф. Ніцше є предметом дослідження не одного покоління вітчизняних та зарубіжних філософів. Місце та роль філософії життя у становленні духовно-академічної філософії досліджувалися Н.Г. Мозговою. Вплив ніцшеанства на російську релігійну філософію вивчає Т.Д. Суходуб. Так, проблема надлюдини відображена у роботах Н.Н. Ємельянової, І.П. Ярославцевої, А.А. Лаврової, Г.О. Камбал; проблемою нігілізму займались Т.В. Лютий, I.В. Силуянова; С.І. Шаповал досліджував етику $\Phi$. Ніцше.

До аналізу проблеми людини у творчості $\Phi$. Ніцше звернувся М.К. Михайловський у статті «Ще про Ніцше», яка була опублікована у журналі «Русское богатство» у 1894 році. Особистість для Ф. Ніцше була самоціллю. М.К. Михайловський наголошував на тому, що індивідуалізм $\Phi$. Ніцше не має нічого спільного з егоїзмом. Дослідник зауважує, що німецький філософ є творцем нової моралі, і як суворий мораліст найбільшою цінністю людини він вважає ï діяльність, за допомогою якої особистість розкриває свої можливості. «Верховним критерієм моральної оцінки у нього є не просте підтримання людського роду, а його покращення» $[1$, с. 971].

На неординарність думок $Ф$. Ніцше стосовно розуміння моралі вказує В.Ф. Чиж у праці «Ніцше як мораліст». На його думку, характерною особливістю, яка відрізняє Ніцше від інших мислителів, є те, що він поділяє людей на сильних творців та слабких рабів. Варто погодитись із думкою В.Ф. Чижа про те, що Ф. Ніцше взагалі не вимагав від людей чогось понад їхні власні сили, тому вимоги висував до кожного різні відповідно до їхніх здібностей та можливостей. Правильною є думка про те, що лише той, хто поверхнево вивчає $\Phi$. Ніцше, може звинуватити його у грубому егоїзмі. Його вчення є лише свідченням того, що кожен, хто читає ці твори, зможе знайти виправдання своїм будь-яким вчинкам: гідним або ні. У зв'язку з цим можна побачити безліч відмінних інтерпретацій творів Ф. Ніцше. Сутність його вчення, як зазначає В.Ф. Чиж, полягає в тому, щоб допомогти людині стати діяльною, не зупинятись на досягнутому, творити саму себе.

Погляди Ф. Ніцше стосовно традиційної моралі є предметом вивчення багатьох дослідників.
Так, А. Фульє у своїй праці «Критика Альфреда Фульє морального вчення Ніцше» зазначав, що мораль $\Phi$. Ніцше така ж важлива для дослідження, як і релігія, оскільки виступає як дух тогочасної епохи. А. Фульє справедливо вважає Ф. Ніцше людиною, яка, заперечуючи загальноприйняту мораль, прагне створити нову. "Вчення Ніцше $€$ не просто моральним скептицизмом - воно є антиморальним догматизмом» [2, с. 3]. Дослідник не погоджується з $\Phi$. Ніцше в тому, що мораль принижує людину. Автор праці вказує на низку протиріч у філософії Ф. Ніцше. А. Фульє зазначає, що $\Phi$. Ніцше, заперечуючи сенс на землі, все ж таки прагне, щоб надлюдина стала сенсом життя. Говорячи про те, що нічого цінного немає, Ф. Ніцше хоче створити щось цінне. Егоїзм є основою життя, проте, на думку німецького філософа, велика любов до життя також потрібна. Такі антиномії свідчать про метафоричність та алегоричність думок $\Phi$. Ніцше.

Про суперечливий характер роздумів Ф. Ніцше писав у своїй праці «Філософія Ніцше» князь Трубецькой. На думку автора, у Ф. Ніцше змогли поєднатися песимізм та оптимістична віра у сенс життя та його вищих представників. Мета, на думку Ф. Ніцше, вигадана людиною і є результатом їі суб'єктивної творчості, з іншого боку, вища людина є метою всього процесу розвитку. Якщо людина не може обгрунтувати мету свого існування, то, як вважав Ф. Ніцше, потрібно зробити все для того, щоб виправдати своє існування. Заради поставленої мети можна й померти. Проаналізувавши ці слова, можемо зрозуміти, що характер цієї мети є суб'єктивним, оскільки людині вона потрібна лише для неї самої. Є.М. Трубецькой зазначав, що мета, згідно з думкою Ф. Ніцше, у кожного індивідуальна. Як тоді цей факт узгоджується із закликами до пошуку загальної мети для всього людства? Якщо ж немає сенсу, то чи доречно говорити навіть про суб'єктивну мету існування? Суперечливі думки вбачає Є.М. Трубецькой у тому, як Ніцше оцінював світовий процес. Оскільки світ у певний момент свого існування завершений, то світовий процес не можна вважати прогресивним поступом, а розуміти його лише таким, що не має ніякого сенсу. Однак, незважаючи на це, 
Ф. Ніцше все ж таки хоче надати світовому процесу сенсу. Щодо мистецтва, то тут також можна говорити про суперечності, оскільки у ньому поєднуються два начала. 3 одного боку, за допомогою діонісійського мистецтва трагедія розкриває весь тягар індивідуального існування, з іншого боку, аполлонівське мистецтво здатне взяти у полон своєю магією, яка веде нас у вир оманливого життя. Таким чином, аполлонівсько-діонісійське начало відображає боротьбу двох протилежностей, а саме песимізму $\Phi$. Ніцше та його оптимізму, а також віру філософа у те, що, незважаючи на відсутність сенсу, його варто шукати. На підтвердження цієї думки можна сказати, що завдання кожного з нас полягає у тому, щоб «внести сенс в оточуюче середовище, звільнити себе та інших від беззмістовного тваринного бажання» [3, с. 17].

Є.M. Трубецькой представив широкий спектр поглядів Ф. Ніцше стосовно критики тогочасної моралі, цінності людського розуму, соціально-демократичних поглядів, сутності та сенсу світового процесу, місця людини у світі, ідеї надлюдини. Він наголошує на тому, що Ф. Ніцше визнає, 3 одного боку, духовне вдосконалення людини, яке є метою всього людства, а з іншого боку, ідею беззмістовної волі до могутності. Можна зробити висновок, що Є.М. Трубецькой вважав ідею надлюдини сповіддю її автора, що відкриває нам двері у внутрішній світ Ф. Ніцше. Незважаючи на те, що він так відкрито виступав проти Бога, Є.М. Трубецькой зумів розгледіти, що Ніцше був релігійною людиною, яка заперечує те, чим живе, тому усі його філософські пошуки є свідченням сили тієї релігійної ідеї, яку він сам проповідував. Така оцінка філософських поглядів Ф. Ніцше допомагає дослідникам його творчості написати той позитивний портрет німецького філософа, на який він, безумовно, заслуговує.

Про Ф. Ніцше як про філософа, який мріяв допомогти людині піднятися на вищий щабель розвитку, визволити її з рабства тогочасних моральних норм, писав у своїй праці «Добро у вченні гр. Толстого і Ніцше» Лев Шестов. Він, безсумнівно, правий у тому, що велика заслуга $\Phi$. Ніцше полягає у тому, що німецький філософ знайшов у собі мужність говорити про проблеми тоді, коли інші мовчки спостерігали. На думку Л.І. Шестова, Ф. Ніцше як глибоко релігійна людина прагнув завдяки християнству звільнитися від тієї відрази до життя, що полонила його. Ф. Ніцше, звичайно, був свідомий того, що вибраний ним шлях філософа-пророка, який піддає нищівній критиці увесь тогочасний суспільний лад, не обіцяв йому нічого, окрім вічних тривог та болючої самотності. Проте, незважаючи на це, якась могутня внутрішня сила штовхала його на пошуки сенсу у цьому знеціненому світі.

Свої погляди на філософію Ф. Ніцше виклав Томас Манн у праці «Філософія Ніцше у світлі нашого досвіду». Автор праці вважає німецького філософа особистістю історичного значення. На думку Т. Манна, на формування філософських поглядів Ф. Ніцше вплинули дві омани. Перша 3 них полягала в тому, що Ф. Ніцше надавав великого значення інстинктам людини, применшуючи роль інтелекту, а друга - в тому, що він вважав життя та мораль протилежними одне одному. Т. Манн вважає, що Ф. Ніцше у своїй праці «Про користь та шкоду історії для життя» заперечував позитивну роль історичного процесу. Т. Манн зазначає, що Ф. Ніцше нічого не говорить про те, яку ж позитивну роль відіграє історія для людства. Аналізуючи висловлювання Т. Манна щодо позиції Ф. Ніцше, можемо зробити логічний висновок про те, що Т. Манн був категорично незгідний із такою точкою зору німецького філософа. Т. Манн вважав, що такі поняття, як «сократизм», «теоретична людина», «свідомість», у Ф. Ніцше отримали іншу назву, а саме «християнська мораль». Причину таких атак на мораль і водночас спорідненість із нею Т. Манн вбачає у внутрішній суперечності Ф. Ніцше. Незважаючи на те, що Т. Манн не завжди погоджувався з філософом, він цілком слушно заявляв про те, що, попри усі омани, Ф. Ніцше з любов'ю ставився до майбутнього, тому усі наступні покоління не переставатимуть цікавитись цим трагічним мислителем.

Аналіз моральних учень Ф. Ніцше виклав С.Л. Франк у своїй праці «Фр. Ніцше і етика «любові до далекого»». С.Л. Франк поставив собі за мету визначити специфіку моральної системи німецького філософа через його заперечення традиційної моралі тогочасного суспільства. С.Л. Франк говорить про недоцільність трактування стилю та мови Ф. Ніцше через їхню метафоричність, тому С.Л. Франк не критикує, а прагне пояснити, чому Ф. Ніцше заперечував обов'язок, співчуття, любов до ближнього, хоче відшукати причини, що спонукали німецького філософа до цього. С.Л. Франк намагається очима Ф. Ніцше побачити стан речей тогочасного суспільства. Надлюдина Ніцше стоїть «по той бік добра і зла», тому у їі житті немає місця боротьбі зі злом. Така людина прагне змінити основу життя. Сенс існування надлюдини полягає у боротьбі проти слабких людей, м'якість яких повинна змінитись на мужність, силу тіла та духу. «Міцність духу як необхідна умова суспільно-моральної творчості і боротьби є основним постулатом етики «любові до далекого»» $[4$, с. 21]. Ідею нерівності людей i панування одних над іншими С.Л. Франк трактує не як здобуття політичної чи соціальної влади, а як духовне панування, зумовлене внутрішньою силою людини. 3 цього випливає, що Семен Франк вказує на те, що аристократизм Ніцше не передбачає історичний аристократизм, який базується на політичній, соціальній та економічній владі па- 
нівного класу. Знайомлячись із працею, доходимо висновку, що стосовно основних ідей Ф. Ніцше, a саме ідеї надлюдини, волі до влади, погляди С.Л. Франка відповідають поглядам Ф. Ніцше.

Ф. Ніцше, як вважав Вальтер Вейман-Вейє у своїй праці «Ніцше як історична дійсність», дав нову моральну релігію, яка аж ніяк не має нічого спільного з аморалізмом. Ф. Ніцше зірвав 3 життя пелену, що приховувала його сутність ще з часів Декарта, і показав його таким, яким воно $€$ насправді. Життя - це вічне становлення, хаос, iз якого народжуються дійсно справжні риси людини, а саме бажання до влади, сили, гармонії і нестримної енергії життєвих сил.

На гідну оцінку заслуговує книга професора В.Б. Кучевського «Філософія нігілізму Фрідріха Ніцше». Автор вважає, що основними ознаками філософії Ф. Ніцше є нігілізм та ірраціоналізм. «Тотальний нігілізм у філософії Ніцше виступає не просто послідовним намаганням говорити «ні» усьому загальнообов' язковому та загальнозначущому і тому ніби такому, що протистоїть самості «Я» людини, а своєрідним способом і методом його теоретичного аналізу» [5, с. 17]. Ірраціоналізм Ф. Ніцше полягає у запереченні розумного начала як у світі, так і в людині. Логічні протилежності у висловлюваннях Ніцше В.Б. Кучевський пов' язував із ірраціоналізмом у логіці філософських роздумів філософа. Абсурдність $€$ характерною рисою філософії Ф. Ніцше, а його твори хоч і відрізняються своїми назвами, проте є дивовижно схожими за своїм змістом. Вони є наче оркестром, що грає одну музику. В.Б. Кучевський висуває цікаву думку про те, що повторення одних і тих же проблем у творах філософа, рух його думок - усе це дуже нагадує вічне вороття. Хоча, як вважає В.Б. Кучевський, у філософії Ф. Ніцше відсутні повна система та еволюція поглядів, проте є низка ідей, які гідні уваги дослідників, а саме нігілізм, переоцінка усіх цінностей, воля до влади, вічне вороття. Ознайомившись із роботою В.Б. Кучевського, доходимо висновку, що він не обійшов увагою жодну з ідей філософа, проаналізувавши творчу сторону $Ф$. Ніцше.

До проблеми нігілізму у творчості Ф. Ніцше звертався Г.О. Рачинський у своїй праці «Трагедія Ніцше». Автор зазначає, що нігілізм Ф. Ніцше не є чисто індивідуальним твердженням, тому що тогочасний стан суспільства потребував критики та переоцінки. Г.О. Рачинський справедливо зауважив, що «ніцшеанство є запереченням всієї європейської культури, починаючи від Сократа i закінчуючи Кантом» [6, с. 997]. Автор праці зумів показати антираціоналістичне спрямування нігілізму Ф. Ніцше, своєрідну критику тогочасної науки та розуму як постійних супутників моралі добра і зла. Ф. Ніцше протиставляв аполлонівську ясність і раціоналізм стихійному та темному діонісійському началу.
Мартін Хайдеггер у своїй праці «Ніцше» найбільш докладно проаналізував проблему нігілізму. Філософ дослідив історію нігілізму, починаючи з XVIII століття, коли Ф.Г. Якобі вперше вжив це поняття. На думку М. Хайдеггера, справжня історія нігілізму починається з Ф. Ніцше, котрий під цим терміном розумів історичний рух, що був проголошений під девізом «Бог помер». Як вважав Ф. Ніцше, нігілізм як звільнення від усіх попередніх цінностей і створення нових був необхідний.

Ірунтовний аналіз таких понять, як «воля до влади», «вічне вороття», «надлюдина», «європейський нігілізм», подає німецький поет та мислитель Георг Юнгер у своїй книзі «Ніцше». У цій праці автор прагне віднайти ті точки дотику, що поєднують досвід людини ХХ століття з досвідом Ф. Ніцше. У розділі «Воля до влади» Г. Юнгер вивчає проблему нігілізму Ф. Ніцше, в результаті чого доходить висновку, що «нігілізм не позаду нас, а ми знаходимось всередині його. Однак у той же час ми зайняті роботою, спрямованою на його подолання» [7, с. 106]. Щодо вічного вороття, то Г. Юнгер, як і Ф. Ніцше, вбачає зв'язок вороття зі світобудовою. Хоча слід зазначити, що трактування концепції «вічного вороття» зазнає критики з боку Г. Юнгера, який вважає, що Ф. Ніцше не відійшов від ньютонівського уявлення про час і простір. Щоби пояснити, у чому полягав сенс вороття, Г. Юнгер застосовує феноменологію пам'яті і сприйняття. За її допомогою він фіксує, що вороття визначає будову світу, в якому ми існуємо. Книга Г. Юнгера була не лише критичною. Автор прагнув зрозуміти логіку думок Ф. Ніцше, причину їх двоїстості. На його думку, характер філософії Ф. Ніцше, суперечності у висловлюваннях були пов' язані з тим, що він був і мислителем, і художником. Таке поєднання є непоєднуваним. Творчість Ніцше, як справедливо вважає Г. Юнгер, не пристосовується до тієї чи іншої політичної ситуації або епохи, оскільки велика філософія не має меж.

Про Ф. Ніцше як про філософа, слова якого не потрібно розуміти буквально, писав у своїй праці «Ніцше» ЖТіль Дельоз. Він застерігає усіх, хто буде знайомитись із творчою спадщиною філософа, від помилок тлумачення тих чи інших його ідей. У Ф. Ніцше воля до влади не передбачає панування одних людей над іншими, адже їі сутність полягає у тому, щоби творити, а не брати. Говорячи про сильних та слабких людей, Ф. Ніцше не мав на увазі їхній соціальний стан, адже, як правильно помітив Ж⿱. Дельоз, сила чи слабкість залежить від міцності чи, навпаки, немічності духу людини. Стосовно «вічного вороття», то буде неправильним розуміння цього процесу як безкінечного повернення до того самого. «Вічне вороття» схоже на колесо, яке розганяє і знищує рабську мораль, нечисту совість, співчуття, тобто усе те, що заважає людині вільно дихати 
на шляху до гармонійного та повноцінного життя. Думки Ж․ Дельоза про ключові ідеї Ф. Ніцше мають неабияке позитивне значення для дослідників, які прагнуть зрозуміти та вивчити істинну сутність вчення $\Phi$. Ніцше.

Як про шукача ілюзій, руйнівника старих цінностей та творця нових писав П.С. Юшкевич у статті «Фрідріх Ніцше і філософія ілюзії». Автор наголошує на неонтологічному статусі ілюзій Ф. Ніцше. Впродовж усього свого життя він прагнув вирішити проблемні питання, що пов'язані зі смертю Бога, втратою сенсу життя, які стали причиною знецінення людини та їі існування. Не існує ні «справжнього», ні «вигаданого» світу, а є лише вічне становлення та ілюзія буття. «Ніцше як філософ «трагічного пізнання і «приборкання науки», про яке він писав, або сарказми над божевільною і нескромною «волею до істини» не означають, що Ніцше шукав порятунок в самообмані та брехні» [8, с. 125].

За допомогою пізнання неможливо знайти відповіді на важливі питання, не може допомагати воно у боротьбі проти духовної кризи, що зветься нігілізмом. Причина цього полягає у релятивізації всього сущого та падінні абсолютистського світосприйняття. Як зазначає П.С. Юшкевич, Ф. Ніцше став жертвою власних ілюзій, а проблематика його творів робить їх одним цілим, що прагне за допомогою естетичних ілюзій подолати ілюзорність буття.

М.О. Бердяєв у статті «Ніцше і сучасна Німеччина» переконливо заявляє, «що той дослідник, який цитує Ніцше дослівно, ніколи не зрозуміе його, адже Заратустру та його слова потрібно навчитись відгадувати" [9, с. 2]. М.О. Бердяєв відкидає думки інших учених про те, що вчення $\Phi$. Ніцше можна якимось чином пов'язати з політикою. Більш того, філософські шукання німецького філософа йшли в розріз зі станом тогочасної Німеччини. На думку М.О. Бердяєва, Ф. Ніцше як релігійна людина, втративши віру у вище благо, розпочав пошуки благ з іще більшим ентузіазмом. Результатом цих пошуків стала індивідуальність як вище начало, тому не дивно, що найвищим ідеалом для Ф. Ніцше була "надлюдина», яку М.О. Бердяєв вважав релігійно-метафізичною ідеєю. М.О. Бердяєв впевнений у тому, що людина повинна стати надлюдиною. Він переконаний, що надлюдина є шляхом від людини до Бога.

Критичний огляд літератури дає змогу констатувати, що тим тлом, на якому $\Phi$. Ніцше вибудовував картину життя тогочасного суспільства, була криза моралі та занепад внутрішньої сили людини. Можна зробити висновок на основі досконалого аналізу творів цих авторів, що мораль тогочасного суспільства була тим імпульсом, який спонукав Ніцше до пошуку горизонтів, які б відкрили людині новий стиль життя. Аналіз джерел засвідчує, що існують різні аспекти дослідження філософії Ф. Ніцше, які безпосередньо стосуються трактування сенсу життя. Дослідивши та проаналізувавши всі аспекти, можемо стверджувати, що падіння традиційної моралі, нігілізм, «воля до влади», надлюдина є тими підвалинами, на яких вибудовується принципово нове некласичне уявлення Ф. Ніцше про сенс життя.

\section{Jimepamypa}

1. Михайловский Н.К. Литературные воспоминания. Полное собрание сочинений. Санкт-Петербург : Типография М.М. Стасюлевича, 1909. Т. 7. С. 923-975.

2. Фулье А. Критика Альфреда Фулье нравственного учения Ницше / пер. с фр. В.В. Дроздова. Москва, 1902. $39 \mathrm{c}$.

3. Трубецкой Е.Н. Философия Ницше. Критический очерк. Москва : Типолитография т-ва Ч.Н. Кушнарев и $\mathrm{K}^{\circ} ., 1904.159 \mathrm{c}$.

4. Франк С.Л. Фр. Ницше и этика «любви к дальнему». Приложение к журналу «Вопросы философии». Москва : Правда, 1990. С. 21-29.

5. Кучевский В.Б. Философия нигилизма Ф. Ницше. Москва, 1996. 166 с.

6. Рачинский Г.А. Трагедия Ницше: опыт психологии личности. Ч. 1 : Дионис и Аполлон. Вопросы философии и психологии. 1900. № 55. С. 963-1010.

7. Юнгер Ф.Г. Ницше / пер. с нем. А.В. Михайловского. Москва : Праксис, 2001. 256 с.

8. Юшкевич П.С. Фридрих Ницше и философия эгоизма. Новая жизнь. 1911. № 13. С. 113-138.

9. Бердяев Н.А. Ницше и современная Германия. Биржевые ведомости. 1915. № 14650. С. 2.

\section{Анотація}

Павлишин Л. Г. Основні ідеї Ф. Ніцше у працях дослідників його творчості. - Стаття.

У статті розглянут філософські та етичні аспекти творчої спадщини Ф. Ніцше. Людина тогочасного суспільства більше не відчувала себе захищеною. Якщо руйнується стара ієрархія цінностей, то перш за все це свідчить про те, що порядки, які створювала до цього часу людина, вже не мають ніякої цінності. Якщо особа прагне рівності з їй подібними, то ким вона може стати врешті-решт? Поки людина відчуває себе подобою Бога, на це запитання є однозначна відповідь. Однак якщо Бог помер для людини, то що ж відбувається за цих обставин? Кому ж тепер буде уподібнюватись людина? Люди, що вірили в одного лише морального Бога, втратили його, прирекли себе на самотність. Саме через ці обставини на допомогу людині повинна прийти вища людина. Слід зазначити, що вчення про «вічне вороття» і надлюдина взаємопов'язані. Там, де потік вороття досягає найбільшої сили, приходить надлюдина, яка виникає посередині шляху. Якщо б цього не трапилось, то вчення про «вічне вороття» було б неможливим і абсурдним, адже за цих обставин залишилося б лише механічне вороття, що повторюється як кругообіг. Це вічне циклічне становлення отримує сенс у надлюдині.

У Ф. Ніцше теорія вищої людини є критикою, що розкриває найглибшу і найнебезпечнішу містифікацію гуманізму. Вища людина повинна вести людство 
до досконалості, аж до повної їі здійсненності. Вона повинна відновити в собі всі якості людини, подолати їі відчуженість, здійснити ідеал цілісної людини, поставити її на місце Бога. Проте людина не знає, що значить стверджувати і самостверджуватися. Їй здається, що це означає розуміти і витримувати випробовування, і чим важчі вони і частіше їй дістаються, тим краще. Для людини реальним є все те, що давить і гнітить. Для неї критерієм активності виступають всі ті, хто перебуває під пресом життєвих обставин, напружується з усіх сил. Піднесена або вища людина готова і до себе поставитися суворо й твердо, вшановуючи суворість і недоступність.

Ключові слова: людина, мораль, нігілізм, абсурд, цінність, надлюдина, воля до влади.

\section{Summary}

Pavlyshyn L.H. The main ideas of F. Nietzsche in the works of researchers of his creative heritage. - Article.

The article deals with the philosophical and ethical aspects of creative heritage F. Nietzsche. Person of contemporary society no longer felt protected. If the old hierarchy of values is destroyed, then first of all it indicates that the orders that a person has created so far have no value. If a person seeks equality with the likes of him, then who can he become after all? As long as a person feels like God, there is an unequivocal answer to this question. But if God died for man, what happens under these circumstances? Who will be like a person now? People who believed only in a moral God, lost it, they dodged themselves to loneliness. And a higher person should come to the aid of man because of these circumstances. It should be noted in this case that the doctrines of eternal reversal and superhuman are interrelated. Superhuman who arises in the middle of the path comes where the flow of turn reaches the greatest force. If this had not happened the doctrine of eternal perpetual reversal would have been impossible and absurd. After all, under these circumstances, only a mechanical turn would remain, which is repeated as a cycle. This eternal cyclical formation makes sense in the superhuman. For F. Nietzsche, the theory of the supreme man is a critization that reveals the deepest and most dangerous hoa fission of humanism. The supreme man must lead mankind to perfection until its full feasibility. He must restore all the qualities of man, overcome his alienation, fulfill the ideal of a holistic person, and put himself in the place of God. However, a person does not know what "affirm" and "self-affirmation" means. It seems that this means to understand and withstand the problems. And it is better if these problems are hard and often take place. Everything that is sneering and oppressing is real for a person. All those who are under the press of life circumstances, straining with their best are the criterion of activity. An exalted or strong person is ready to treat herself strictly and firmly, honoring the severity and inaccessibility.

Key words: man, morality, nihilism, absurd, value, superman, will to power. 